\title{
PELAKSANAAN QUESTION STUDENT HAVE METHOD DALAM MENINGKATKAN HASIL BELAJAR PADA MATA PELAJARAN EKONOMI DI SMA
}

\author{
Firman Aryansyah \\ Program Studi Pendidikan Akuntansi, Universitas Galuh, Jl. R. E. Martadinata No.150, Ciamis, Indonesia \\ Email: firmanaryansyah0@gmail.com
}

\begin{abstract}
Low learning achievement or student learning outcomes is a problem that is the main topic in educational institutions. This can be seen from the failure to achieve the minimum completeness criteria (KKM). For this reason, it is necessary to apply learning methods that can improve student learning outcomes. The objectives of this study were to: 1) Obtain a description of the improvement of student learning outcomes using conventional learning methods at the initial and final measurements; 2) Obtain an overview of the improvement of student learning outcomes using the Question Student Have learning method at the initial and final measurements. This research method is experimental research with Non equivalent Control Group Design. The population of this research is SMA N 1 Banjarsari. Based on the results of the study, it shows that: 1) There is a difference in the learning outcomes of students in the experimental class 1 with the average pre-test score achievement of 55.29 and the posttest average score of 86.91. The experimental class 1 got an average $\mathrm{N}$-Gain value of 0.71 (high); 2) There are differences in the learning outcomes of students in the experimental class 2 with the average pretest achievement of 54.39 and the average posttest score of 83.10. The experimental class 1 got an average $\mathrm{N}$-Gain value of 0.63 (moderate) and 3) There is a difference between the learning outcomes of students using conventional learning methods and the learning outcomes of students using the Question Student Have learning method. The results of the $F$ test calculation which states that the calculated price obtained from the posttest results is 2.035 and the table price is 1.851. The results of the analysis show that fcount> ftable, it can be said that learning using conventional learning methods is more effective than learning using the Question Student Have learning method.
\end{abstract}

Keywords: Question Student Have Method, The Result of learning

\begin{abstract}
ABSTRAK
Rendahnya prestasi belajar atau hasil belajar siswa merupakan masalah yang menjadi topik utama di Lembaga Pendidikan. Hal ini dapat tergambar dari tidak tercapainya Kriteria Ketuntasan Minimal (KKM). Untuk itu diperlukan penerapan metode pembelajaran yang dapat meningkatkan hasil belajar siswa. Tujuan dari penelitian ini adalah untuk: 1)Memperoleh gambaran tentang peningkatan hasil belajar siswa menggunakan metode pembelajaran Konvensional pada pengukuran awal dan akhir; 2)Memperoleh gambaran tentang peningkatan hasil belajar siswa menggunakan metode pembelajaran Question Student Have pada pengukuran awal dan akhir. Metode penelitian ini adalah penelitian eksperimen denga Non equivalent Control Group Design. Populasi penelitian ini adalah SMA N 1 Banjarsari. Berdasarkan hasil penelitian menunjukan bahwa: 1)Terdapat perbedaan hasil belajar siswa kelas eksperimen 1 dengan pencapaian nilai rata-rata pretest 55,29 dan nilai rata-rata posttest 86,91 . Kelas eksperimen 1 mendapatkan nilai ratarata N-Gain 0,71 (tinggi); 2)Terdapat perbedaan hasil belajar siswa kelas eksperimen 2 dengan pencapaian nilai ratarata pretest 54,39 dan nilai rata-rata posttest 83,10. Kelas eksperimen 1 mendapatkan nilai rata-rata N-Gain 0,63 (sedang) dan 3)Terdapat perbedaan antara hasil belajar siswa menggunakan metode pembelajaran Konvensional dengan hasil belajar siswa menggunakan metode pembelajaran Question Student Have. Hasil perhitungan Uji F menyatakan bahwa harga fhitung yang diperoleh dari hasil posttest yakni sebesar 2,035 dan harga ftabel sebesar 1,851. Hasil analisis menunjukan $f_{\text {hitung }}>\mathrm{f}_{\text {tabel, }}$ maka dapat dikatakan bahwa pembelajaran dengan menggunakan metode pembelajaran Konvensional lebih efektif dibandingkan dengan pembelajaran menggunakan metode pembelajaran Question Student Have.
\end{abstract}

Kata Kunci: Hasil Belajar, Metode Pembelajaran Question Student Have

Cara sitasi: Aryansyah, F. (2021). Pelaksanaan Question Student Have Method dalam Meningkatkan Hasil Belajar pada Mata Pelajaran Ekonomi di SMA. J-KIP (Jurnal Keguruan dan IImu Pendidikan), 2 (1), 91-98. 


\section{PENDAHULUAN}

Hasil belajar merupakan kemampuan yang dimiliki oleh siswa setelah mendapatkan pengalaman belajarnya. Hasil belajar siswa mencakup beberapa ranah diantaranya ranah kognitif, afektif dan psikomotorik. Menurut Rusman (2015) "hasil belajar adalah sejumlah pengalaman yang diperoleh siswa yang mencakup ranah kognitif, afektif, dan psikomotorik".

Menurut Sudjana (2016) "hasil belajar adalah kemampuan-kemampuan yang dimiliki siswa setelah ia menerima pengalaman belajarnya". Pengertian hasil belajar menurut Bloom (Sudjana, 2016) diklasifikasi menjadi tiga ranah, yaitu ranah kognitif, ranah afektif dan ranah psikomotoris.

1. Ranah kognitif berkenaan dengan hasil belajar intelektual yang terdiri dari enam aspek, yakni pengetahuan atau ingatan, pemahaman, aplikasi, analisi, sistesis, dan evaluasi. Kedua aspek pertama disebut kognitif tingkat rendah dan keempat aspek berikutnya termasuk kognitif tingkat tinggi.

2. Ranah efektif berkenaan dengan sikap yang terdir dari lima aspek, yakni penerimaan, jawaban atau reaksi, penilaian, organisasi, dan internalisasi.

3. Ranah psikomotoris berkenaan dengan hasil belajar kerampilan dan kemampuan bertindak. Ada enam aspek psikomotoris, yakni (a) gerkan refleks, (b) keterampilan gerakan dasar, (c) kemampuan perseptual, (d) keharmonisan atau ketepatan, (e) gerakan keterampilan kompleks, dan (f) gerakan ekspresif dan interpretatif.

Rendahnya prestasi belajar atau hasil belajar siswa merupakan masalah yang menjadi topik utama di Lembaga Pendidikan. Hal ini dapat tergambar dari tidak tercapainya Kriteria Ketuntasan Minimal (KKM), yaitu nilai terendah yang ditetapkan oleh pihak Lembaga Pendidikan setelah pendidik melakukan musyawarah terlebih dahulu. Banyak faktor yang dapat mempengaruhi hasil belajar siswa rendah, faktor ini juga bisa timbul dari pendidik seperti: penyampaian materi yang masih menggunakan metode lama tanpa menggunakan metode pembelajaran yang dapat mendukung proses pembelajaran agar lebih efektif dan menyenangkan, selain dari faktor pendidik hal ini juga dipengaruhi oleh karakteristik siswa yang berbeda-beda dan pada umumnya sering mudah jenuh dengan proses pembelajaran.

Belajar adalah "suatu proses usaha yang dilakukan seseorang untuk memperoleh suatu tingkah laku yang baru secara keseluruhan, sabagai hasil pengalamannya sendiri dalam interaksi dengan lingkungannya" merupakan pengertian belajar menurut Slameto (2015). Seorang dikatakan belajar apabila memperoleh perubahan tingkah laku yang baru dialami sendiri dalam interaksi dengan lingkungannnya. Definisi tersebut sejalan dengan pendapat Cronbach (Djamarah, 2011) menyatakan bahwa "learning is shown by change in behavior as a result experience". (dengan kata lain belajar adalah perubahan tongkah laku sebagai hasil dari pengalaman. Sementara menurut Spears (Hamdani, 2011) mengemukakan bahwa "Learning is a observe, to read, to initiate, to try spmething themselves, to listen, to follow direction." (belajar adalah mengamati, membaca, berinisiasi, mencoba sesuatu sendiri, mendengarkan, mengikuti petunjuk).

Pembelajaran merupakan suatu sistem lingkungan belajar yang terdiri dari unsur: tujuan, bahan pelajaran, strategi, alat, siswa, dan guru. Semua unsur atau komponen tersebut saling berkaitan, saling mempengaruhi, dan semuanya berfungsi dengan berorientasi kepada tujuan. Pemilihan dan penentuan metode pembelajaran merupakan salah satu komponen pengajaran yang harus diperhatikan dalam kegiatan belajar mengajar, karena metode pembelajaran yang digunakan akan berpengaruh terhadap proses pembelajaran, kemudian akan berpengaruh terhadap hasil belajar siswa.

Penerapan metode pembelajaran yang diterapkan oleh pendidik dalam proses pembelajaran sangat berpengaruh terhadap berhasil tidaknya kegiatan pembelajaran. Menurut Slameto (2013) menyatakan bahwa "Metode belajar yang kurang baik akan mempengaruhi belajar siswa yang tidak baik pula. sehingga siswa kurang senang terhadap pelajaran atau gurunya, akibatnya siswa malas untuk belajar". 
Keberhasilan atau kegagalan dalam belajar mengajar merupakan sebuah ukuran dalam proses pembelajaran. Salah satu keberhasilan menandakan bahwa tujuan pembelajaran telah tercapai dengan memperhatikan beberapa hal yang dijadikan tolak ukur atas keberhasilan dalam proses pembelajaran. Menurut Djamarah dan Zain (2010) yang menjadi petunjuk bahwa suatu proses belajar mengajar dianggap berhasil adalah hal-hal sebagai berikut:

1. Daya serap terhadap bahan pengajaran yang diajarkan mencapai pretasi tinggi, baik secara individual maupun berkelompok.

2. Perilaku yang digariskan dalam tujuan pengajaran/instruksioanl khusus (TIK) telah dicapai oleh siswa baik secara individual maupun kelompok.

Menurut Hosnan (2014) "Metode Question Student Have digunakan untuk mempelajari tentang keinginan dan harapan siswa sebagai dasar untuk memaksimalkan potensi yang mereka miliki. Metode ini menggunakan sebuah teknik untuk mendapatkan partisipasi siswa melalui tulisan. Hal ini sangat baik digunakan pada siswa yang kurang berani mengungkapkan pertanyaan, keinginan, dan harapan-harapannya melalui percakapan".

Kegiatan pembelajaran ingin mencapai hasil belajar yang maksimal, tetapi tidak semua siswa dapat memperoleh hasil belajar yang baik atau mendapatkan nilai di atas KKM, adapun siswa yang memperoleh hasil belajar yang rendah atau yang belum memenuhi KKM. Pendidik harus mampu menciptakan suasana belajar yang baik sehingga siswa dapat menguasai materi dengan baik. Oleh karena itu pendidik perlu menerapkan metode yang tepat agar dapat meningkatkan hasil belajar dan keaktifan siswa. Metode yang dapat digunakan diantaranya metode Question Student Have.

Menurut Djamarah (2011), Metode Question Student Have maksudnya "Pelajaran dimulai dari pertanyaan siswa. Tehnik ini merupakan tehnik yang tidak menakutkan yang dapat dipakai untuk mengetahui kebutuhan dan harapan siswa. Tehnik ini menggunakan potensi kreativitas membangun pertanyaan dalam memperoleh partisipasi siswa secara tertulis". Sementara menurut Hosnan (2014) Metode Question Student Have digunakan untuk mempelajari tentang keinginan dan harapan siswa sebagai dasar untuk memaksimalkan potensi yang mereka miliki. Metode ini menggunakan sebuah teknik untuk mendapatkan partisipasi siswa melalui tulisan. Hal ini sangat baik digunakan pada siswa yang kurang berani mengungkapkan pertanyaan, keinginan, dan harapan-harapannya melalui percakapan.

Sedangkan metode Question Student Have yang dikemukakan oleh Silberman (2014) menyatakan bahwa "metode ini merupakan cara yang tidak membuat siswa takut untuk mempelajari apa yang mereka dibutuhkan dan diharapakan. Cara ini memamfaatkan tehnik yang mengundang partisipasi melalui penulisan, bukannya pembicaraan".

Salah satu upaya yang dapat dilakukan oleh seorang pendidik dalam menggaktifkan siswa pada saat proses pembelajaran adalah memberikan kesempatan kepada siswa untuk mengajukan pertanyaan dan menjawab pertanyaan dari pendidik maupun temannya yang mana pertanyaan tersebut berkaitan dengan materi yang sudah diajakan. Dengan memberikan kesempatan kepada siswa untuk bertanya berarti telah membantu siswa dalam menyiapkan diri dalam proses belajar, sebab semakin banyak aktivitas yang dikerjakan oleh siswa, maka dapat berpengaruh besar terhadap peningkatan hasil belajar.

Syah (2015) mengemukakan bahwa:

a. Pendekatan belajar (approach to learning) dan strategi atau kiat melaksanakan pendekatan serta metode belajar termasuk faktor-faktor yang turut mennetuan efisiensi dan keberhasilan belajar siswa. sering terjadi seorang siswa yang memiliki kemampuan ranah cipta (kognitif) yang lebih tinggi daripad teman-temannya, ternyata hanya mampu mencapai hasil yang sama dengan yang dicapai teman-temannya itu. Bahkan, bukan hal yang mustahil jika suatu saat siswa cerdas tersebut mengalami kemorosotan pretasi sampai ke titik yang lebih rendah daripada prestasi temannya yang berkapasitas rata-rata. 
b. Sebaliknya, seorang siswa yang sebenarnya hanya memiliki kemampuan ranah cipta rata-rata atau sedang, dapat mencapai puncak prestasi (sampai batas optimal kemampuannya) yang memuaskan, lantaran menggunakan pendekatan belajar yang efisien dan efektif. Konsekuensi positifnya ialah harga diri (self-esteem) siswa tersebut melonjak hingga setara dengan temantemannya, yang beberapa orang di antaranya mungkin berkapasitas kognitif lebih tinggi.

berikut:

Berdasarkan latar belakang penelitian, selanjutnya penulis merumuskan masalah sebagai

1. Apakah terdapat peningkatan hasil belajar siswa dengan menggunakan metode question student have pada pengukuran awal (pretest) dan pengukuran akhir (posttest) di kelas eksperimen?

2. Apakah terdapat perbedaan hasil belajar dengan menggunakan metode question student have di kelas eksperimen dan konvensional di kelas kontrol?

\section{METODE PENELITIAN}

Metode penelitian yang digunakan dengan bertitik tolak dari rumusan masalah dan tujuan penelitian yang telah dirumuskan sebelumnya, oleh peneliti untuk menemukan pengaruh variabel $X$ terhadap $Y$ yaitu dengan menggunakan metode eksperimen. Menurut Sugiyono (2010) bahwa "Metode penelitian eksperimen dapat diartikan sebagai metode penelitian yang digunakan untuk mencari pengaruh perlakuan tertentu terhadap yang lain dalam kondisi yang terkendalikan".

Metode penelitian yang digunakan adalah metode penelitian eksperimen. Sugiyono (2010) menyatakan bahwa "Metode penelitian eksperimen dapat diartikan sebagai metode penelitian yang digunakan untuk mencari pengaruh perlakuan tertentu terhadap yang lain dalam kondisi yang dikendalikan". Desain eksperimen yang digunakan yaitu Nonequivalent Control Group Design yang dapat digambarkan pada Tabel 1.

Tabel 1. Design Eksperimen

\begin{tabular}{cccc}
\hline Kelas & Tes awal & Treatment & Tes Akhir \\
\hline Eksperimen & $\mathrm{O}_{1}$ & $\mathrm{X}_{1}$ & $\mathrm{O}_{2}$ \\
Kontrol & $\mathrm{O}_{3}$ & & $\mathrm{O}_{4}$ \\
\hline
\end{tabular}

Sumber: Sugiyono (2010)

Keterangan:

$\mathrm{O}_{1}$ : Tes awal (pretest) sebelum perlakuan diberikan kepada kelas eksperimen.

$\mathrm{O}_{2}$ : Tes akhir (posttest) setelah perlakuan diberikan kepada kelas eksperimen.

$\mathrm{O}_{3}$ : Tes awal (pretest) sebelum pembelajaran diberikan kepada kelas kontrol.

$\mathrm{O}_{4}$ : Tes akhir (posttest) setelah pembelajaran diberikan kepada kelas kontrol.

$X$ : Perlakuan (treatment) dengan menggunakan media pembelajaran audio visual pada kelas eksperimen.

Populasi dalam penelitian ini adalah keseluruhan siswa kelas X IPS SMA Negeri 1 Banjarsari tahun pelajaran 2020/2021, yang terbagi menjadi lima kelas yaitu, X IPS 1, X IPS 2, X IPS 3, X IPS 4, dan X IPS 5. Berdasarkan data jumlah siswa kelas X IPS 1 sebanyak 33 orang siswa, kelas X IPS 2 sebanyak 34 orang siswa, kelas X IPS 3 sebanyak 29 orang siswa, kelas X IPS 4 sebanyak 34 orang siswa, kelas X IPS 5 sebanyak 34 orang siswa. Sehingga total seluruh populasi adalah 164 orang. Dari lima kelas yang ada, dua kelas dipilih dengan teknik Sampling Purposive, Sugiyono (2010) "Sampling Purposive adalah teknik penentuan sampel dengan pertimbangan tertentu". Data hasil belajar dalam penelitian ini dikumpulkan dengan tes hasil belajar. Sampel pada penelitian ini ditentukan dengan menggunakan teknik sampling berupa tehnik simple random sampling (sampel acak sederhana). Pengambilan sampel acak sederhana dapat dilakukan dengan 
cara undian. Untuk menentukan kelas eksperimen 1 dan 2 akan dilakukan secara acak sederhana dengan menggunakan undian setelah dilakukannya pretest.

Berdasarkan data diketahui bahwa nilai rata-rata pretest siswa kelas X IPS di SMA Negeri 1 Banjarsari tidak jauh berbeda. Kelas X IPS 1 memperoleh nilai rata-rata 53,37. Kelas X IPS 2 memperoleh nilai rata-rata 52,65. Kelas X IPS 3 memperoleh nilai rata-rata 55,19 . Kelas X IPS 4 memperoleh nilai rata-rata 54,10 . Kelas X IPS 5 memperoleh nilai rata-rata 52,45 . Berdasarkan nilai rata-rata pretest tersebut, dan yang terpilih yaitu:

1. Kelas X IPS 3, kelas ini diperlakukan sebagai kelas eksperimen.

2. Kelas X IPS 4, kelas ini diperlakukan sebagai kelas kontrol.

Selanjutnya, hasil penelitian ini dianalisis dengan rumus $\mathrm{N}$-Gain dan rumus Uji-t dengan taraf signifikan 0,05.

Berdasarkan kerangka pemikiran maka hipotesis yang diajukan dalam penelitian ini yaitu:

1. Terdapat perbedaan hasil belajar siswa yang menggunakan metode pembelajaran question student have berupa video pada pengukuran awal (pre-test) dan pengukuran akhir (post-test).

2. Terdapat perbedaan hasil belajar siswa yang menggunakan metode pembelajaran konvensional pada pengukuran akhir (post-test).

\section{HASIL DAN PEMBAHASAN}

Berdasarkan hasil penelitian dapat diketahui bahwa hasil belajar siswa dengan penerapan metode pembelajaran Question Student Have dikelas eksperimen 1 yakni X IPS 3 memperoleh nilai rata-rata yang baik apabila dilihat dari Kriteria Ketuntasan Minimal (KKM). Penerapan metode Question Student Have pada mata pelajaran Ekonomi kelas eksperimen (X IPS 3) di SMA Negeri 1 Banjarsari menunjukan adanya peningkatan yang signifikan dari hasil belajar siswa sebelum dan sesudah menggunakan metode pembelajaran question student have. Hal tersebut, dapat dilihat dari pengukuran awal dan pengukuran akhir, peningkatan hasil belajar siswa dengan menggunakan metode ini termasuk dalam kategori sedang.

Peningkatan hasil belajar belajar siswa dapat terjadi karena metode pembelajaran Question Student Have merupakan metode pembelajaran yang melibatkan keaktifan siswa dalam kegiatan pembelajaran dengan harapan agar memperoleh partisipasi siswa secara tertulis. Sehingga proses pembelajaran dapat aktif, kreatif, efektif dan menyenangkan dengan mengetahui kebutuhan dan harapan yang dimiliki siswa.

Tahapan pembelajaran yang dilaksanakan sesuai dengan pendapat Hosnan (2014). Langkah-langkah metode Question Student Have sebagai berikut:

1. Bagikan kartu kosong kepada siswa.

2. Mintalah setiap siswa menulis beberapa pertanyaan yang mereka miliki tentang mata pelajaran atau sifat pelajaran yang sedang dipelajari.

3. Putarlah kartu tersebut searah keliling jarum jam. Ketika setiap kartu diedarkan pada peserta berikutnya, peserta tersebut harus membacanya dan memberikan tanda cek di sana jika pertanyaan yang mereka ajukan sama.

4. Saat kartu kembali pada penulisnya, setiap peserta lebih memeriksa semua pertanyaan yang diajukan oleh kelompok tersebut. Fase ini akan mengindentifikasi pertanyaan mana yang banyak dipertanyakan. Jawab masing-masing pertanyaan tersebut dengan cara berikut.

a. Jawaban langsung atau berikan jawaban yang berani.

b. Menunda jawaban dari pertanyaan-pertanyaan tersebut sampai waktu yang tepat.

c. Meluruskan pertanyaan yang tidak menunjukan suatu pertanyaan.

d. Pangggil beberapa peserta berbagi pertanyaan secara sukarela, sekalipun pertanyaan mereka tidak memperoleh suara terbanyak

e. Kumpulkan semua kartu, kartu tersebut mungkin berisi pertanyaan-pertanyaan yang mungkin dijawab pada pertemuan berikutnya. 
Metode pembelajaran Question Student Have memiliki kelebihan seperti yang dikemukakan oleh Ningsih (2014) sebagai berikut:

1. Dapat melatih keterampilan bertanya siswa.

2. Dapat membina tanggung jawan individu dan kelompok.

3. Mengembangkan pola pikir sendiri.

Metode pembelajaran Question Student Have memiliki kekurangan sesuai dengan yang dikemukakan oleh Ningsih (2014) sebagai berikut:

1. Diperlukan waktu yang cukup lama dalam menerapkan strategi pembelajaran aktif.

2. Dikhawatirkan ada siswa yang melihat pertanyaan-pertanyaan kawannya, hal ini membuat penerapan strategi ini tidak maksimal.

Keterkaitan antara metode pembelajaran dengan hasil belajar tergantung pada penerapan dan pemilihan metode pembelajaran yang tepat diterapkan oleh pendidik dalam proses pembelajaran sangat berpengaruh terhadap berhasil tidaknya kegiatan pembelajaran.

Proses pembelajaran dengan menggunakan metode Question Student Have ini dilaksanakan selama 12 jam pelajaran atau 4 kali pertemuaan. Dalam setiap pertemuan pendidik menyampaikan kompetensi yang ingin dicapai, pendidik menyampaikan materi pengajaran secara singkat, lalu siswa dibagi menjadi beberapa kelompok yang terdiri dari 4 atau 5 orang untuk masingmasing kelompok. Kemudian siswa diminta membuat pertanyaan pada kertas kosong yang telah disediakan tentang materi yang ingin diketahui jawabannya. Selanjutnya kartu diputar dan di bacakan, bila ada pertanyaan yang sama beri tanda centang $(\sqrt{ })$. Kemudian jawaban diberikan oleh pendidik dari centangan yang paling banyak terus hingga centangan paling sedikit. Adapun jika tidak ingin mengggunakan waktu yang lama, pertanyaan-pertanyaan tersebut dapat dikumpulkan tanpa harus diputar, kemudian jawa beberapa pertanyaan secara acak tanpa mengabaikan keterlibatannya dengan tujuan pembelajaran. Dengan kompetensi yang dimiliki pendidik mengenai wawasan dan pengetahuan yang tinggi dengan menjawab pertanyaan dari siswa membuat kelas menjadi lebih hidup dalam pembelajaran.

Berdasarkan langkah-langkah pembelajaran yang telah dijelaskan, dapat disimpulkan bahwa siswa dengan cara memaksimalkan potensi kreativitas membangun pertanyaan dalam memperoleh partisipasi siswa secara tertulis. Dengan memberi kesempatan kepada siswa untuk bertanya berarti telah membantu siswa dalam menyiapkan diri dalam proses belajar. Adapun semakin banyak aktivitas yang dikerjakan oleh siswa, maka dapat berpengaruh besar terhadap peningkatan hasil belajar. Oleh sebab itu penerapan metode pembelajaran Question Student Have dapat meningkatkan hasil belajar siswa kelas eksperimen (X IPS 3 ).

Penelitian yang telah dilakukan oleh peneliti dapat membuktikan bahwa pengggunaan metode pembelajaran Konvensional dengan metode pembelajaran Queston Student Have berpengaruh terhadap hasil belajar siswa. Dengan hasil belajar siswa kelas eksperimen (X IPS 3) dan kelas kontrol (X IPS 4) pada pengukuran awal (pretest) dan pengukuran akhir (posttest) yang dihitung dengan menggunakan rumus N-Gain, dimana hasil untuk kelas eksperimen 1 berada pada kategori tinggi dan untuk kelas kontrol berada pada kategori sedang.

Dalam penggunaan metode tersebut tentu mempunyai perbedaan hasil belajar siswa. Hal tersebut terjadi karena tingkat pemahaman dari masing-masing siswa berbeda. Kemudian juga didasari dari proses belajar yang berbeda pula. Pada kelas eksperimen (X IPS 3) siswa belajar dengan cara mengamati, berdiskusi, memberikan komentar atau pendapat, serta memberikan solusi atau rekomendasi tentang gambar atau poster tersebut. Dengan cara mengamati gambar tersebut disertai dengan diskusi antar anggota kelompok dapat membantu siswa lebih berfikir luas, aktif, kreatif dan sistematis. Sehingga proses pembelajaran ini dapat membantu siswa yang lainnya yang kurang dapat memahami pelajaran yang cepat.

Sedangkan pada kelas eskperimen (X IPS 3) dengan penerapan metode Question Student Have ini, bahwa pembelajaran dimulai dari pertanyaan siswa. Siswa diminta membuat pertanyaan 
tentang materi yang akan dibahas sesuai dengan tujuan pembelajaran maupun tentang materi yang ingin diketahui jawabannya. Hal ini dikarenakan pendidik dalam menyampaikan materi secara singkat. Selanjutnya dalam hal ini, kemampuan yang dimiliki pendidik dalam menjawab setiap pertanyaan dengan tepat dan secara luas dapat mengembangkan pola pikir siswa.

Metode pembelajaran merupakan salah satu hal penting dalam kegiatan belajar mengajar, maka dari itu sebelum memberikan pengajaran seorang pendidik perlu mempertimbangkan metode pembelajaran yang akan digunakan dalam proses pembelajaran yang sesuai dengan kompetensi yang miliki siswa. Sehingga pendidik akan mampu mencapai tujuan pembelajaran. Penerapan metode pembelajaran yang diterapkan oleh pendidik dalam proses pembelajaran sangat berpengaruh terhadap berhasil tidaknya kegiatan pembelajaran. Hal tersebut sejalan dengan pendapat Slameto (2013) menyatakan bahwa "Metode mengajar yang kurang baik akan mempengaruhi belajar siswa yang tidak baik pula. Sehingga siswa kurang senang terhadap pelajaran atau gurunya, akibatnya siswa malas untuk belajar". Dengan demikian penggunaan metode pembelajaran Konvensional dan Question Student Have memiliki peran yang positif dalam meningkatkan hasil belajar siswa, akan tetapi hasil belajar yang diperoleh dengan menggunakan metode Konvensional lebih tinggi dibandingkan dengan penggunaan metode Question Student Have.

\section{KESIMPULAN}

Kesimpulan dari penelitian ini adalah: 1)Terdapat perbedaan hasil belajar siswa kelas eksperimen 1 dengan pencapaian nilai rata-rata pretest 55,29 dan nilai rata-rata posttest 86,91. Kelas eksperimen 1 mendapatkan nilai rata-rata N-Gain 0,71 (tinggi); 2)Terdapat perbedaan hasil belajar siswa kelas eksperimen 2 dengan pencapaian nilai rata-rata pretest 54,39 dan nilai rata-rata posttest 83,10. Kelas eksperimen 1 mendapatkan nilai rata-rata N-Gain 0,63 (sedang) dan 3)Terdapat perbedaan antara hasil belajar siswa menggunakan metode pembelajaran Konvensional dengan hasil belajar siswa menggunakan metode pembelajaran Question Student Have. Hasil perhitungan Uji $\mathrm{F}$ menyatakan bahwa harga fhitung yang diperoleh dari hasil posttest yakni sebesar 2,035 dan harga $f_{\text {tabel }}$ sebesar 1,851 . Hasil analisis menunjukan $f_{\text {hitung }}>f_{\text {tabel, }}$, maka dapat dikatakan bahwa pembelajaran dengan menggunakan metode pembelajaran Konvensional lebih efektif dibandingkan dengan pembelajaran menggunakan metode pembelajaran Question Student Have.

\section{REKOMENDASI}

Agar diskusi dapat berjalan efektif maka poster sebaiknya dibagikan ke setiap anggota kelompok sehingga setiap anggota kelompok dapat mengamati dengan seksama poster tersebut secara bersamaa.

\section{UCAPAN TERIMAKASIH}

Penulis menyampaikan terima kasih kepada kepala SMA N 1 Banjarsari yang telah mendukung terhadap pelaksanaan penelitian ini.

\section{DAFTAR PUSTAKA}

Djamarah, S. B., \& Zain, A. (2010). Strategi Belajar Mengajar. Jakarta: Rineka Cipta.

Djamarah, S. B. (2011). Psikologi Belajar. Jakarta: PT Rineka Cipta.

Hamdani. (2011). Strategi Belajar Mengajar. Bandung: Pusaka Setia.

Hosnan. (2014). Pendekatan Saintifik dan Kontekstual dalam Pembelajaran Abad 21 Kunci Sukses Implementasi Kurikulum 2013. Bogor: Ghalia Indonesia. 
Ningsih, R. A. S. (2014). Pengaruh Penerapan Questions Student Have dalam Pembelajaran Matematika Terhadap Hasil Belajar dan Aktivitas Siswa Mts Negeri Bukit Raya Pekanbaru. Skripsi. Pekan Baru: Fakultas Tarbiyah dan Keguruan Universitas Islam Negeri Sultan Syarif Kasim Riau. 08 februari 2017, 8:39)

Rusman. (2015). Pembelajaran Tematik Terpadu. Jakarta: PT Raja Grafindo Persada.

Silberman, M. L. (2014). Active Learning; 101 Cara Belajar Siswa Aktif. Bandung: Nuansa Cendekia.

Slameto. (2013). Belajar dan Faktor-faktor yang mempengaruhi. Jakarta: PT. Rineka Cipta.

Sudjana, N. (2016). Penilaian Hasil Proses Belajar Mengajar. Bandung: PT Remaja Rosdakarya.

Sugiyono. (2010). Metode Penelitian Pendidikan (Pendekatan Kuantitatif, Kualitatif, dan R\&D). Bandung: CV. Alfabeta.

Syah, M. (2015). Psikologi Belajar. Jakarta: PT Raja Grafindo Persada.

Tari, H. D ., Suwirta, U., \& Dedeh. (2020). Pengaruh Penerapan Model Pembelajaran Kooperatif Tipe Teams Games Tournament (TGT) terhadap Hasil Belajar Peserta Didik pada Mata Pelajaran Ekonomi di MAN 2 Kota Tasikmalaya. J-KIP (Jurnal Keguruan dan IImu Pendidikan), 1 (2), 19-26. 